PROBLEMS

OF EDUCATION IN THE $21^{\text {st }}$ CENTURY Vol. 79 , No. 3, 2021

360

\title{
EMOTIONAL INTELLIGENCE AND STUDENTS' ACADEMIC ACHIEVEMENT
}

\author{
Abdo Hasan AL-Qadri, Wei Zhao \\ Shaanxi Normal University, China \\ E-mail: lubna23112015@outlook.com,zhaowei@snnu.edu.cn
}

\begin{abstract}
Emotional Intelligence (EI) is essential attribution among school learners of today. In this respect, determination and normalization of the measures to investigate and recognize dimensions levels help educators have a successful intervention and increase students' academic achievement level. This research aimed to explore the relationship between Emotional Intelligence (EI) and the academic achievement of Arabic basic school students in China. Further, it also sought to determine the level of students' emotional intelligence and motivation to learn. The research aims are addressed through a tool that explores emotional intelligence and motivation. A 60-item for initial emotional intelligence scale was utilized and analyzed to test their psychometric properties by pilot testing. A final total of 303 students with ages ranged between 12-16 years old participated in the research. The research findings suggested the final formulation of items of the emotional intelligence scale that can measure the levels of emotional intelligence of students along with a significantly positive relationship to academic achievement. There were statistically significant differences in the respondents' level of emotional intelligence according to the gender variable. In comparison, there were no statistically significant differences in the respondents' level of emotional intelligence according to the grade variable. Recommendations of the research were presented.
\end{abstract}

Keywords: emotional intelligence, academic achievement, factor analysis, development and relationship

\section{Introduction}

Since the 1990s, researchers come to study emotional intelligence in depth by examining the possible outcomes of relating EI to the outcomes of psychology or education. Recently, emotional intelligence (EI) has won an important place in the academic and scientific circles (Mortan et al.,2014). Emotional Intelligence (EI) comes up with a new pattern which would help educationalists to better understanding and corelating success and educational environment (Coşkun \& Öksüz, 2018). In the 2000s, Reuven Bar-On collaborated to describe the important factors for success in life. The obtained results showed that a number of intelligences and non-cognitive factors effectively affects the individual's success in life. At a later time in 1985, Reuven Bar-On also created the term EQ (Emotional Quotient) to assess general intelligence. Bar-On demonstrated that emotional intelligence is an effective predictor of an employee's career and personal life. He suggested a 5-point scale of emotional intelligence, which looks at the quality of each of the five components of emotional intelligence as follows: intrapersonal skills, interpersonal skills, stress control, the ability to adapt and general mood (Yahaya et al., 2012).

In general, Bar-On claims that, because both emotional and cognitive intelligence have an equal relationship to general intelligence, both contribute equally to one's overall success in life. It is claimed by Strenberg (1998) to say that cognitive capacity is insignificant to scientific achievement would be ridiculous. Such skill requires a relatively high standard to be accepted to a graduate science program at a university. However, once you are accepted, what matters is less about having a lot of IQ and more about how you and your peers compare to one another. 
Authors put forward the theory that intelligence is purpose-driven and requires a more efficient processing. Intelligence is a social and cultural phenomenon, and behavior that is considered adaptive in one culture may be considered maladaptive in another (Bar-On, 2006).

Good academic performance is undoubtedly having the same opinion of educational psychologists (Vahedi \& Nikde, 2011). In their attempt to investigate the key factors that determine academic outcomes, the researchers have come to question many unanswered questions. In recent years, it has been found that academic success is influenced by such variables as family, school, society, and the environment (Khajehpour,2011). Also, Wood et al. (2009), note that a majority of previous studies have focused on the impact of demographic and socio- psychological variables on academic achievement. The emotional intelligence is a critical quality for today's school students. In this regard, determining and normalizing the measures used to investigate and understand dimension levels assist educators in having an effective intervention and increasing students' academic achievement levels.

\section{Literature Review}

Emotional Intelligence is the ability to process information related to one's emotions and the ability to use the information as a guide for understanding and acting. The concept of Emotional Intelligence (EI) defined as "the ability to monitor one's own and others' feelings and emotions., to discriminate among them and to use this information to guide one's thinking and actions" (Carolyn MacCann et al., 2011). To Bar-On, emotional intelligence deals with oneself, others, and the environment. Therefore, it should be more adaptive to changing conditions and to be more successful in meeting environmental demands. People who score high on the EQ-i, tend to be better at understanding their own emotions and communicating them appropriately.

Intrapersonal: The ability to deal with and reflect one's and others' thoughts, feelings and behaviors, as well as the competence to use the most suitable resources to face and interact with every personal and specific social situation (Franco et al., 2017). It has been associated with: quality of the relationships with classmates and teachers, academic performance, lower learning difficulties, students' motivation, their will to engage in scholar tasks and cooperate with others (Henricsson \& Rydell, 2006; Sternberg, 2015). Bar-On (1997) defined IQ communication to be the ability to recognize and manage emotions. People who score high on the EQ-i, tend to be better at understanding their own emotions and communicating them appropriately.

Interpersonal: In the Bar-On, 1997 study, the Interpersonal EQ-i was tested for the interpersonal relationships factor. People with high interpersonal EQ tend to have positive social interactions, pay attention to and understand others' feelings, and process them well. They refer to the ability to recognize emotions in other's speech and interpret what people are feeling. Empathy is the ability to recognize empathy and to generate empathy for others. A capacity for dealing with others is necessary to remain emotionally balanced. It mainly involves the ability to identify emotions and empathize with others (Shearer, 2004).

Stress management: Both flexibility and emotional control are expressed as the ability to change how one feels in different situations. This component includes independent, internal, and positive thinking (Bar-On \& Parker, 2000). Individuals with high-stress management skills tend to remain calm during stressful situations and usually respond calmly in stressful times.

Adaptability: The paper focuses on how one successfully copes with environmental demands and how one's ability to size up and deal with problematic situations plays a role in this. The adaptability threshold is high (Bar-On, 1997).

Scherer (2015) defined adaptability as a competency that allows the person to be flexible and be able to alter one's feelings. It refers to one's abilities in switching emotionally and behaviorally from one state to another. Those who score highly in adaptability are flexible, realistic, and able to deal with change well, especially in a good way. 
PROBLEMS

OF EDUCATION IN THE $21^{\text {st }}$ CENTURY Vol. 79 , No. 3, 2021

362

General mood: The Optimism and Happiness scales consist of two subcomponents. These components of EI focus on one's overall outlook on life and one's emotional contentment. High scores on these psychological attributes show a positive outlook, enabling people to face challenges more positively. This research indicates how optimistic people tend to remain bright and upbeat. Somatic characteristics, such as being nervous, help handle difficult or stressful situations (Bar-On \& Parker, 2000).

\section{The Relationship between EI and Academic Achievement:}

There has been a support for the assumed link between high EI and academic success (Van Rooy \& Viswesvaran, 2004); however, some studies have not been able to clarify the direction of relationships (Woitaszewski \& Aalsma, 2004). An intensive meta-analysis by Van Rooy \& Viswesvaran (2004) found a significant evidence of positive associations of EI with school performances.

Different researchers studying EI have used a variety of assessment instruments, providing an array of results. Swart (1996) worked with nearly 500 students at traditional universities using the emotional quotient inventory by Bar-On (1997). The results supported a positive relationship between the variables for academically successful students who demonstrated significant higher emotional intelligence compared to unsuccessful students (Parker et al., 2004).

A study by Rode et al. (2007) revealed that emotional intelligence is connected to academic achievement due to the connection between emotional intelligence and general academic achievement. The most important reason is that academic performance involves a wide range of potential difficulties. The primary reason for this is the high demand placed on students to self-direct their academic work, requiring high self-management levels. Individuals with high emotional intelligence understand the factors that will impact their success. That is why individuals with high emotional intelligence would perform better academically.

Achievement is strongly connected to the development of humans in general in shaping the child's cognitive, emotional, social and physical abilities (Preeti, 2013). People who are considered emotionally intelligent are mostly able to achieve better whatever they do (Goleman, 1995). By teaching emotional and social skills in schools, the ability to succeed in academics will be improved. Emotionally intelligent students would have improved academic achievement and would be at a greater likelihood of academic success (Joibari \& Mohammadtaheri, 2011).

The overall academic performances of pupils are not precisely assessed without incorporating their emotional intelligence and overall intelligence. Further, students' academic achievement in the classroom is an indication of many factors, some of which are related to EI, classroom management and the diverse factors are related to the peculiarities of the surrounding. This study intends to develop comprehensive test materials for the Emotional Intelligence aspects of learning. Therefore, assessing the links between EI and Arabic school students' academic achievement is significant due to the lack of studies in this area and most of the results on this issue have derived from the West. This research looks at the connection between Emotional Intelligence and the influence of cultural differences on students' academic achievement. Hence, this study serves as one of the most important studies that have explored this area.

The main purpose of the research was to examine the psychometric properties and then the relationship among emotional intelligence and academic achievement:

- Develop a diagnostic tool to be a standard for measuring the emotional intelligence of Arabic school students.

- Determine the levels of emotional intelligence of Arabic school students.

- Identify whether there are any differences in the degree of Emotional Intelligence, according to (Gender-Grade) variables.

Academic and emotional development are the primary goals of schools. It might be 
disastrous if emotional intelligence is neglected as an important and necessary role for schools and communities. An Emotional Intelligence (EI) helps create harmony among students, and students will be more self-assured when they are having to deal with the problems and difficulties or challenges of living and learning at educational institutions. Emotional Intelligence is comprised of interrelated emotional and social competencies and skills that determine how effectively people manage themselves, understand others, communicate with them and cope with daily demands and pressures (Bar-On, 2003), provide tools to measure the emotional intelligence that would help the academicians, researchers, educators and specialists in this field (Khajehpour, 2011), predict the academic achievement through students' scores in emotional intelligence (Zahed-Babelan \& Moenikia, 2010), contribute to solve problems related to low academic achievement (Zahed-Babelan \& Moenikia, 2010), help educators develop programs to raise the emotional intelligence of students (Zahed-Babelan \& Moenikia, 2010), and contribute to the adaption of new methods and strategies to improve the levels of academic achievement of students (Carolyn MacCann et al., 2011).

\section{Research Hypotheses}

- A positive relationship between emotional intelligence and academic achievement of students.

- There are multiple levels for emotional intelligence scores of students.

- There are significant differences between (male-female) gender variable.

- There are significant differences among grade variable groups.

\section{Research Methodology}

\section{Research Design}

A correlational design was used to determine the relationship between emotional intelligence and academic achievement of students according to developed measures with the context of basic Arabian students in China. Gall and Borg in 1996 stated that correlational research designs are highly useful for studying problems in education. The purpose of correlational research is to discover relationships between/among variables through the use of correlational statistics (Castellan, 2010).

\section{Data Collection}

The students met at their schools during October, November, and December of 2019. Prior to meeting, preparations were made, and requests were sent to the school councils of two schools in the district of Guangzhou and two schools in the Yiwu district in the southern part of China. A number of two school boards granted a consent letter. Efforts continued by coordinating with school principals over the phone to facilitate the pilot test.

Some steps were taken in advance to avoid sampling errors. Therefore, the random sample was of an adequate size because the main concern was not the percentage of the sampled research population. It was rather the total size of the sample selected relative to population complexity. Whereas the larger the sample, the less likely the results will be biased, diminishing returns can rapidly be identified when samples exceed a certain size that must be balanced with the researcher's resources (Taherdoost, 2016). Consequently, sampling error reduced at a decreasing rate by larger sample sizes, and statistical formulas were available for defining sample size.

\author{
PROBLEMS \\ OF EDUCATION \\ IN THE $21^{\text {st }}$ CENTURY \\ Vol. 79 , No. 3, 2021 \\ 363
}


PROBLEMS

OF EDUCATION

IN THE $21^{\text {st }}$ CENTURY

Vol. 79, No. 3, 2021

364

Researchers intended to use the statistical equation for sample selection and determined the sample size of the research as follows:

$S=X^{2} N P(1-P) \div d^{2}(N-1)+X^{2} P(1-P)$ (Zulkipli \& Ali, 2018).

\section{Participants}

The research method revealed the necessary parameters for estimating the sample size and the specified sample as a finite component or subset of participants from the target population. Therefore, the target population refers to the whole set of subjects whose features are of interest to the researcher. Following a technique known as statistical descriptive inferential, researchers might draw conclusions about the target population with a high degree of confidence based on the results of a sample. This study focused on (4) Arabic schools in China: Modern Arabic School, Canton Global Academy, Canton Arabic School, and Arabic School. The Scholastic year is (2019-2020). This study covered 303 students (116 males $(38.3 \%)$ and 187 females $(61.7 \%)$ for the $7^{\text {th }}, 8^{\text {th }}$ and $9^{\text {th }}$ Grades. The participants ranged in age from 12 to $16(M=14.36$, $S D=1.11)$ years old. The sample study for final implementation and 50 students for pilot testing were chosen using a random sampling technique.

\section{Research Instruments}

The instruments used in this study were based on various educational works of literature and previous studies on this subject, such as those conducted by (Bar-On \& Parker, 2000).

The validation and development had three steps: experts and specialists' examination, a pilot test, and a final application.

The initial instruments were provided to seven specialists and experts in this field to verify the face validity. A pilot test of the instruments conducted with 50 students to verify the psychometric properties (validity and reliability). The research' instruments have been applied twice within a two-week interval between applications.

Instruments were presented in the final formulation after they had been validated. Furthermore, through the final application of the instruments over the things posed in the instruments in 5- point Likert scale, the researcher determined the degrees of students' agreement (always applicable, almost applicable, sometimes applicable, seldom applicable, and not applicable at all). The instrument of emotional intelligence consists of 60 items as initial formulation, 10 items in Intrapersonal Skills, 14 items in Interpersonal Skills, 12 items in Stress Management, 10 items in Adaptability, and 14 items in General Mood. After implementing the amendments proposed by the panel, it has been agreed to modify, replace, improve some words, and exclude the six following items:

"I like my body", "When I get angry, I act without thinking", "I know when people are upset, even when they say nothing" and "I like the way I look" from the Intrapersonal Skills dimension. "I can tell when one of my close friends is unhappy" and "Even if things get hard, I do not give up" from the Interpersonal Skills dimension.

\section{Data Analysis}

The research data were analyzed using several statistical methods to find out the research outcomes and investigate the research instrument's psychometric properties, using that SPSS 24, Amos 22, and JASP. 


\section{Psychometric Properties of Emotional Intelligence Scale}

The factorial validity was tested for the research tool. KMO value acquired in this study was .89 greater than the values suggested in the literature. The significance of the Chi-squared statistics obtained at the end of the BST displayed the normal distribution of the data with multiple variables. BST was established to be significant $\left(\chi^{2}=1035^{* * *} ; p \leq .001\right)$. These results demonstrated that the EIS was appropriate for factor analysis (Hair, Black, Babin, \& Anderson, 2014), indicating that factor analysis could be carried out when the KMO value was greater than 0.60 (Field, 2009). The most probable number of variables to match the data was five. Initial EFA with Eigenvalues for 46 items revealed a five-factor structure, which was higher than 1 that could be extracted, explained $54.323 \%$ of the total variance. Eight items were excluded $(16,21,25,33,42,44,45$ and 49) because their loadings were not high and had been loaded on more than one factor (Jonker \& Vosloo, 2008; Ki \& Hon, 2008). Results showed that the first factor consisted of 6 items whose factor loads ranged between .57 and .81 , the second factor consisted of 11 items whose factor loads ranged between .50 and .65 , the third factor consisted of 10 items whose factor loads ranged between .58 and .71, the fourth factor consisted of 9 items whose factor loads ranged between .47 and .84 , and the fifth factor consisted of 10 items whose factor loads ranged between .58 and .73 . The communalities values of items ranged between .43 and .68 . The research instrument items have been confirmed by CFA. Figure (1) shows the fit indices for the final measurement model. All fit indices were found to follow the criterion, suggesting that the final five-factor model fit well. By using the following criteria: $\left(\chi^{2} / d f=1.16, \mathrm{CFI}=.91, \mathrm{TLI}=.910, \mathrm{GFI}=.923, \mathrm{AGFI}=.905, \mathrm{RMSEA}=.050\right)$ and the remaining index was also close to a good fit $(\mathrm{NFI}=.897)$ (Heale \& Twycross, 2015). The factor loadings demonstrated that all items of each indicator in the measurement model showed relatively high loadings (Deng \& Chan, 2017; Watkins, 2017). All items were higher than .50 standardized loadings. All factor loadings were statistically significant at $p<.01$. The measurement model and fit indexes were presented in Figure (1). 
PROBLEMS

OF EDUCATION IN THE $21^{\text {st }}$ CENTURY Vol. 79, No. 3, 2021

366
Figure 1

Five-factor Model of EIS Depending on CFA (46-Item)

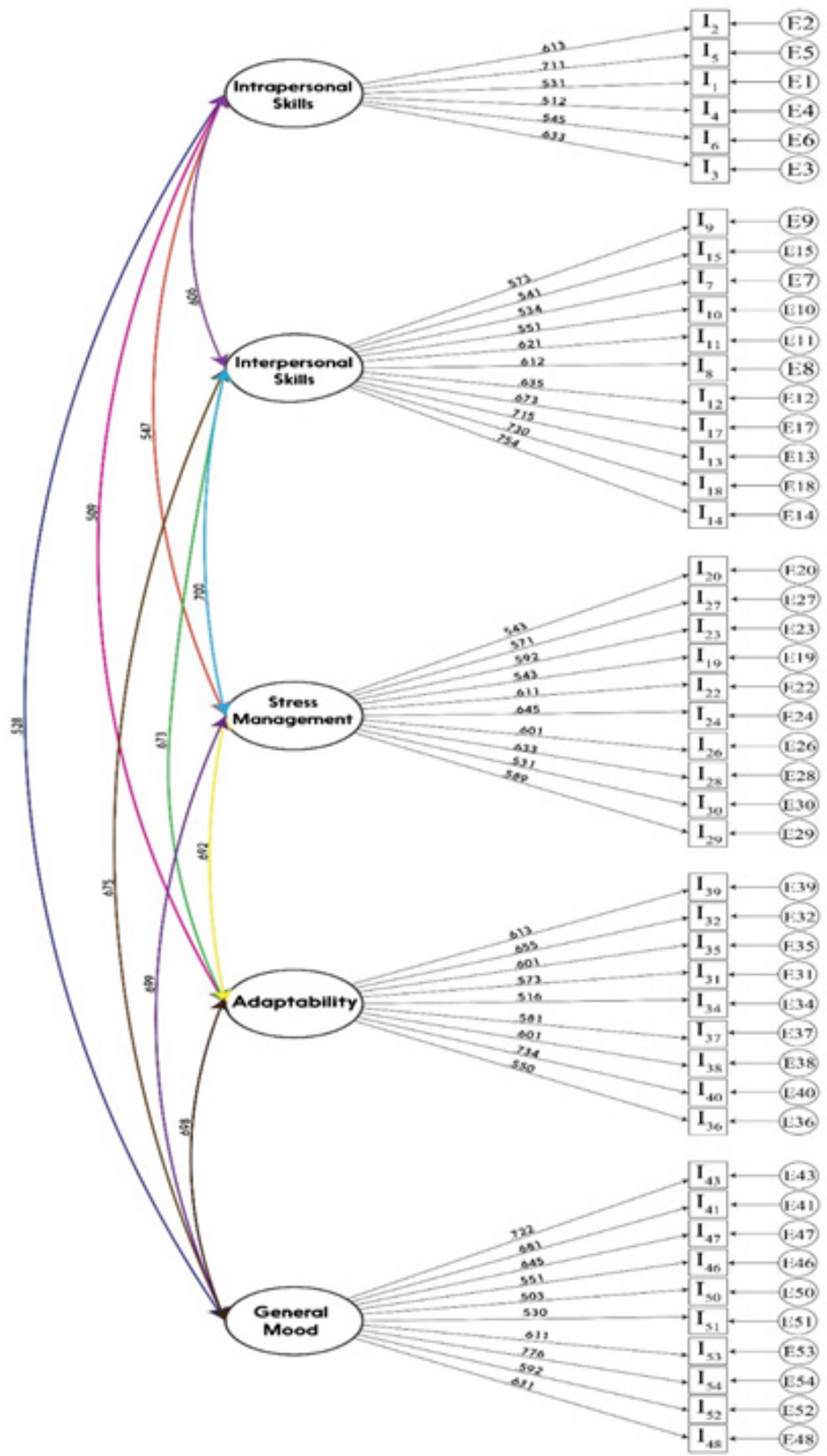


Reliability

PROBLEMS

OF EDUCATION

IN THE $21^{\text {st }}$ CENTURY

Vol. 79, No. 3, 2021

367

The reliability of EI subscale scores in the whole sample was $.79, .81, .83, .86$ and .74 for Cronbach's Alpha, McDonald's Omega, Test Re-Test, Composite Reliability (CR) and Average Variance Extracted (AVE), respectively as mentioned in Table (1). In this regard, researchers have chosen McDonald's Omega to measure reliability as a new coefficient that is recommended according to prior studies to be used for intelligence tests; hence, coefficient alpha may not be an accurate reliability index for the multidimensional scales, which are frequently referred to by researchers. On the contrary, the assumptions of model-based reliability estimate of omega coefficients are usually fewer and more practical than alpha coefficients (Deng \& Chan, 2017; Watkins, 2017). Also, in this instrument, the reliability of each subscale was high and acceptable. In order to examine the internal accuracy of this measure, the Test Re-Test was validated by 50 students who responded to the scale items. Within a two-week interval between applications, students responded twice. The accuracy was 0.831 based on re-testing. This suggested that there was an appropriate stable coefficient predictor (Heale \& Twycross, 2015). Most of the constructs in Table (1) agree with the AVE factor criterion, whereby the AVE factors are always greater than the square correlation $\left(\mathrm{R}^{2}\right)$.

Table 1

Matrix of Reliability Coefficients, AVE and Squared Correlation among EI Factors

\begin{tabular}{|c|c|c|c|c|c|c|c|c|c|c|c|}
\hline Factor & $a$ & $\dot{\omega}$ & $\begin{array}{l}\text { Test } \\
\text { Re- } \\
\text { Test }\end{array}$ & CR & AVE & $1^{\text {st }}$ & $2^{\text {nd }}$ & $3^{\text {rd }}$ & $4^{\text {th }}$ & $5^{\text {th }}$ & Overall \\
\hline $1^{\text {st }}$ & .78 & .79 & .77 & .72 & .60 & _- & $.37^{\circ}$ & $.30^{*}$ & .26 & .28 & $.35^{*}$ \\
\hline $2^{\text {nd }}$ & .82 & .82 & .85 & .80 & .63 & $.61^{\cdots *}$ & - & $.49^{* *}$ & $.45^{\prime \prime}$ & $.46^{*}$ & $.47^{* \prime}$ \\
\hline $3^{\text {rd }}$ & .74 & .75 & .84 & .79 & .62 & $.55^{\cdots *}$ & $.70^{\cdots * *}$ & - & $.48^{* *}$ & $.49^{* *}$ & $.45^{* *}$ \\
\hline $4^{\text {th }}$ & .71 & .73 & .79 & .77 & .60 & $.51^{\cdots *}$ & $.67^{\cdots *}$ & $.69^{* *}$ & - & $.49^{* *}$ & $.43^{* *}$ \\
\hline $5^{\text {th }}$ & .81 & .82 & .80 & .83 & .68 & $.53^{\cdots *}$ & $.68^{\prime * *}$ & $.70^{* * * *}$ & $.70^{* * *}$ & - & $.41^{* *}$ \\
\hline Overall & .79 & .81 & .83 & .86 & .74 & $.59^{\prime * *}$ & $.68^{* * *}$ & $.67^{*+*}$ & $.66^{* * *+}$ & $.64^{* * * *}$ & - \\
\hline
\end{tabular}

\section{Research Results}

The descriptive statistics of EI models scores clarified that factor 5 scored the highest mean $(M=45.62, S D=8.92)$ followed by factor $3(M=31.80, S D=6.84)$, factor $2(M=31.79$, $S D=6.81)$, factor $4(M=27.07, S D=5.98)$, and factor $1(M=27.07, S D=5.99)$ and the overall of EIS $(M=159.38, S D=29.48)$. The mean score of academic achievement was $(M=78.92, S D=$ 9.14). Table (2) provides other descriptive statistics. 
Abdo Hasan AL-QADRI, Wei ZHAO. Emotional intelligence and students' academic achievement

PROBLEMS

OF EDUCATION IN THE $21^{\text {st }}$ CENTURY Vol. 79 , No. 3, 2021

Table 2

Descriptive Statistics of EI Scores

\begin{tabular}{lllllll}
\hline Dimension & $\boldsymbol{N}$ & Range & $\boldsymbol{\Sigma}$ & $\boldsymbol{M}$ & $\boldsymbol{S} \boldsymbol{D}$ & $\boldsymbol{\sigma}^{\mathbf{2}}$ \\
\hline Intrapersonal skills & 303 & 20 & 4880 & 27.07 & 5.99 & 35.85 \\
\hline Interpersonal skills & 303 & 34 & 9631 & 31.79 & 6.81 & 46.34 \\
\hline Stress management & 303 & 34 & 9635 & 31.80 & 6.84 & 46.81 \\
\hline Adaptability & 303 & 33 & 8201 & 27.07 & 5.98 & 35.76 \\
\hline General mood & 303 & 40 & 12944 & 45.62 & 8.92 & 79.50 \\
\hline El (Overall) & 303 & 125 & 48291 & 159.38 & 29.48 & 869.28 \\
\hline Academic Achievement & 303 & 35 & 23914 & 78.92 & 9.14 & 83.62 \\
\hline
\end{tabular}

Note: $\Sigma=$ Sum of scores, $M=$ Mean, $S D=$ Standard deviation, $\sigma^{2}=$ Variance

The first research hypothesis is: A positive relationship between emotional intelligence factors and academic achievement of students for each factor model specifically and Overall. So, the relationships were positive and agreed with the hypothesis. This hypothesis was accepted as follows:

The regression analysis was used to predict academic achievement based on emotional intelligence. Table (3) and Figure display the results of testing the five factors of EI models (2). The findings showed that emotional intelligence and academic achievement have a positive relationship that is statistically important. The significance of each factor of emotional intelligence and the academic achievement of students has been defined by the $\mathrm{F}$ value in addition to defining significance between the overall factor models of emotional intelligence and the academic achievement. It was possible to predict the academic achievement scores through the student's emotional intelligence. The values of the first factor "Intrapersonal Skills" are $(\mathrm{R}$ Square $=.35),(\beta=.59)$ and $(\mathrm{F}$ value $=4.47)$. The second factor "Interpersonal Skills" $(\mathrm{R}$ Square $=.50),(\beta=.71)$ and $(\mathrm{F}$ value $=9.37)$. The third factor "Stress Management" $(\mathrm{R}$ Square $=$ $.49),(\beta=.70)$ and $(\mathrm{F}$ value $=8.92)$. The fourth factor "Adaptability" ( $\mathrm{R}$ Square $=.56),(\beta=.75)$, $(\mathrm{F}$ value $=7.01)$. The fifth factor "General Mood" $(\mathrm{R}$ Square $=.64),(\beta=.80)$, $(\mathrm{F}$ value= 10.10). and Overall $(\mathrm{R}$ Square $=.64),(\beta=.80)$ and $(\mathrm{F}$ value $=7.91)$. So, there was a noticeable effect of emotional intelligence with all its factor models on the academic achievement.

Table 3

Correlations and Regressions between EI Factors and Academic Achievement

\begin{tabular}{lccccc}
\hline Variables & $B$ & $R^{2}$ & Estimate & F-Value & $p$ \\
\hline Intrapersonal Skills $\rightarrow$ Academic Achievement & .59 & .35 & 1.89 & $4.47^{* *}$ & .011 \\
\hline Interpersonal Skills $\rightarrow$ Academic Achievement & .71 & .50 & 2.94 & $9.37^{* * *}$ & .0001 \\
\hline Stress Management $\rightarrow$ Academic Achievement & .70 & .49 & 2.89 & $8.92^{* * *}$ & .0001 \\
\hline Adaptability $\rightarrow$ Academic Achievement & .75 & .56 & 2.51 & $7.01^{* * *}$ & .0001 \\
\hline General Mood $\rightarrow$ Academic Achievement & .80 & .64 & 3.35 & $10,10^{* * *}$ & .0001 \\
\hline Overall $\rightarrow$ Academic Achievement & .80 & .64 & 2.79 & $7.91^{* * *}$ & .0001 \\
\hline Note: $* * \rho \leq .01 ; * * * \rho .001$ & & & & &
\end{tabular}




\section{Figure 2}

The Relationship between EI and Academic Achievement

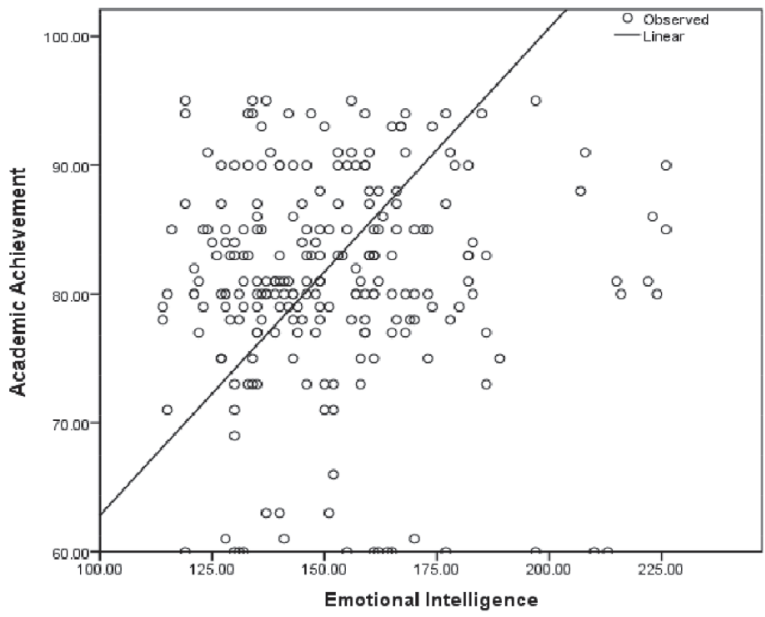

The second research hypothesis is determining the level of emotional intelligence of students with five categories distributed among (very high - high - moderate - low - very low). This hypothesis has been accepted as follows:

The level of each factor in the emotional intelligence scale of students in Arabic schools was determined by calculating the range after calculating arithmetic observations mean for five times.

Range $=\operatorname{maximum}\left(\mathrm{x}_{\mathrm{i}}\right)-\operatorname{minimum}\left(\mathrm{x}_{\mathrm{i}}\right)$. It is worth mentioning that the EIS contains five options. The range was divided by five to determine the length of the category $\left(\mathrm{L}_{1}\right)=20 / 5=4$, $\left(\mathrm{L}_{2}\right)=34 / 5=7,\left(\mathrm{~L}_{3}\right)=34 / 5=7,\left(\mathrm{~L}_{4}\right)=33 / 5=7,\left(\mathrm{~L}_{5}\right)=40 / 5=8$, and $\left(\mathrm{L}_{\text {Overall }}\right)=125 / 5=25$. (Al-Qadri, Wei, Al-khresheh, Chen, \& Hali, 2018). 
Abdo Hasan AL-QADRI, Wei ZHAO. Emotional intelligence and students' academic achievement

PROBLEMS

OF EDUCATION IN THE $21^{\text {st }}$ CENTURY Vol. 79 , No. 3, 2021
Table 4

The Levels of EI of Students

\begin{tabular}{|c|c|c|c|c|c|c|c|c|c|c|c|}
\hline \multicolumn{2}{|c|}{ Dimension } & \multirow{2}{*}{$\begin{array}{l}\text { Very } \\
\text { High }\end{array}$} & \multirow{2}{*}{$\begin{array}{l}\text { High } \\
22-26\end{array}$} & \multirow{2}{*}{$\begin{array}{l}\text { Moderate } \\
17-21\end{array}$} & \multirow{2}{*}{$\frac{\text { Low }}{12-16}$} & \multirow{2}{*}{$\begin{array}{l}\begin{array}{l}\text { Very } \\
\text { low }\end{array} \\
7-11\end{array}$} & \multirow[t]{2}{*}{ Range } & \multirow[t]{2}{*}{$\Sigma$} & \multirow[t]{2}{*}{$M(S D)$} & \multirow[t]{2}{*}{$\%$} & \multirow[t]{2}{*}{$\sigma^{2}$} \\
\hline & The category & & & & & & & & & & \\
\hline \multirow[t]{3}{*}{$1^{\text {st }}$} & $\begin{array}{l}\text { No. of } \\
\text { participants }\end{array}$ & 13 & 60 & 101 & 90 & 39 & \multirow[t]{2}{*}{20} & \multirow[t]{2}{*}{4880} & \multirow[t]{2}{*}{$\begin{array}{l}27.07 \\
(5.99)\end{array}$} & \multirow[t]{2}{*}{54} & \multirow[t]{2}{*}{35.85} \\
\hline & $\%$ & 4 & 20 & 33 & 30 & 13 & & & & & \\
\hline & The category & $\begin{array}{l}47- \\
\text { above }\end{array}$ & $39-46$ & $31-38$ & $23-30$ & $15-22$ & & & & & \\
\hline \multirow[t]{3}{*}{$2^{\text {nd }}$} & $\begin{array}{l}\text { No. of } \\
\text { students }\end{array}$ & 42 & 58 & 82 & 76 & 45 & \multirow[t]{2}{*}{34} & \multirow[t]{2}{*}{9631} & \multirow[t]{2}{*}{$\begin{array}{l}31.79 \\
(6.81)\end{array}$} & \multirow[t]{2}{*}{58} & \multirow[t]{2}{*}{46.34} \\
\hline & $\%$ & 14 & 19 & 27 & 25 & 15 & & & & & \\
\hline & The category & $\begin{array}{l}46- \\
\text { above }\end{array}$ & $38-45$ & $30-37$ & $22-29$ & $14-21$ & & & & & \\
\hline \multirow[t]{3}{*}{$3^{\text {rd }}$} & $\begin{array}{l}\text { No. of } \\
\text { students }\end{array}$ & 35 & 63 & 84 & 70 & 51 & \multirow[t]{2}{*}{34} & \multirow[t]{2}{*}{9635} & \multirow[t]{2}{*}{$\begin{array}{l}31.80 \\
(6.84)\end{array}$} & \multirow[t]{2}{*}{64} & \multirow[t]{2}{*}{46.81} \\
\hline & $\%$ & 11 & 21 & 28 & 23 & 17 & & & & & \\
\hline & The category & 42 -above & $34-41$ & $26-33$ & $18-25$ & $10-17$ & \multirow{3}{*}{33} & \multirow{3}{*}{8201} & \multirow{3}{*}{$\begin{array}{l}27.07 \\
(5.98)\end{array}$} & \multirow{3}{*}{60} & \\
\hline \multirow[t]{3}{*}{$4^{\text {th }}$} & $\begin{array}{l}\text { No. of } \\
\text { students }\end{array}$ & 30 & 48 & 94 & 82 & 49 & & & & & 35.76 \\
\hline & $\%$ & 10 & 16 & 31 & 27 & 16 & & & & & \\
\hline & The category & 45-above & $36-44$ & $27-35$ & $18-26$ & $9-17$ & & & & & \\
\hline $5^{\text {th }}$ & $\begin{array}{l}\text { No. of } \\
\text { students }\end{array}$ & 56 & 131 & 89 & 15 & 12 & 40 & 12944 & $\begin{array}{l}48.62 \\
(8.92)\end{array}$ & 85 & 79.50 \\
\hline & $\%$ & 19 & 43 & 29 & 5 & 4 & & & & & \\
\hline & The category & $\begin{array}{l}182 \\
\text {-above }\end{array}$ & $\begin{array}{l}156- \\
181\end{array}$ & $130-155$ & $\begin{array}{l}104- \\
129\end{array}$ & $78-103$ & & & & & \\
\hline Overall & $\begin{array}{l}\text { No. of } \\
\text { students }\end{array}$ & 43 & 69 & 103 & 57 & 31 & 125 & 48291 & $\begin{array}{l}159.38 \\
(29.48)\end{array}$ & 69 & 869.28 \\
\hline & $\%$ & 14 & 23 & 34 & 19 & 10 & & & & & \\
\hline
\end{tabular}

The third research hypothesis: A statistically significant differences in the Emotional Intelligence of students according to gender (males - females) variable. This hypothesis has been accepted as follows: gender in emotional intelligence was accepted through the differences between males and females and analyzed using an independent T-test. Results are presented in table (5) and figure (3). As the means show, both males and females scored highly in the fifth dimension, "General Mood," but female students scored highest in the entire EIS. There were also statistically significant differences in motivation to learn based on gender, and statistically significant differences in the academic achievement of students based on the same gender variable, demonstrating the positive relationship between emotional intelligence and academic achievement. 
PROBLEMS

OF EDUCATION

IN THE $21^{\text {st }}$ CENTURY

Vol. 79, No. 3, 2021

371

Gender Difference of EI

\begin{tabular}{|c|c|c|c|c|c|c|c|}
\hline Factor & Gander & $\begin{array}{l}\text { No. of } \\
\text { students }\end{array}$ & $M$ & $S D$ & t-test & $d f$ & $p$ \\
\hline \multirow{2}{*}{$1^{\text {st }}$} & Male & 116 & 15.49 & 3.75 & \multirow{2}{*}{$2.12^{*}$} & \multirow{2}{*}{301} & \multirow[t]{2}{*}{.03} \\
\hline & Female & 187 & 19.49 & 4.09 & & & \\
\hline \multirow{2}{*}{$2^{\text {nd }}$} & Male & 116 & 30.59 & 6.22 & \multirow{2}{*}{$2.44^{*}$} & \multirow{2}{*}{301} & \multirow{2}{*}{.02} \\
\hline & Female & 187 & 34.53 & 7.06 & & & \\
\hline \multirow{2}{*}{$3^{\text {rd }}$} & Male & 116 & 30.56 & 6.04 & \multirow{2}{*}{$2.50^{* *}$} & \multirow{2}{*}{301} & \multirow[t]{2}{*}{.01} \\
\hline & Female & 187 & 35.57 & 7.21 & & & \\
\hline \multirow{2}{*}{$4^{\text {th }}$} & Male & 116 & 25.93 & 5.41 & \multirow{2}{*}{$2.63^{* *}$} & \multirow{2}{*}{301} & \multirow{2}{*}{.01} \\
\hline & Female & 187 & 30.77 & 6.22 & & & \\
\hline \multirow{2}{*}{$5^{\text {th }}$} & Male & 116 & 50.24 & 8.68 & \multirow{2}{*}{$3.03^{* *}$} & \multirow{2}{*}{301} & \multirow[t]{2}{*}{.001} \\
\hline & Female & 187 & 57.10 & 11.88 & & & \\
\hline \multirow{2}{*}{ Overall } & Male & 116 & 152.81 & 24.81 & \multirow{2}{*}{$3.10^{* *}$} & \multirow{2}{*}{301} & \multirow{2}{*}{.001} \\
\hline & Female & 187 & 163.45 & 31.42 & & & \\
\hline \multirow{2}{*}{$\begin{array}{l}\text { Academic } \\
\text { Achievement }\end{array}$} & Male & 116 & 76.00 & 8.50 & \multirow{2}{*}{$2.13^{*}$} & \multirow{2}{*}{301} & \multirow{2}{*}{.02} \\
\hline & Female & 187 & 79.88 & 10.13 & & & \\
\hline
\end{tabular}

Note: ${ }^{* *} p \leq .01,{ }^{*} p \leq .05, \Sigma=$ Sum of scores, $M=$ Mean, $S D=$ Standard deviation, $\sigma^{2}=$ Variance

\section{Figure 3}

EI Factors Means

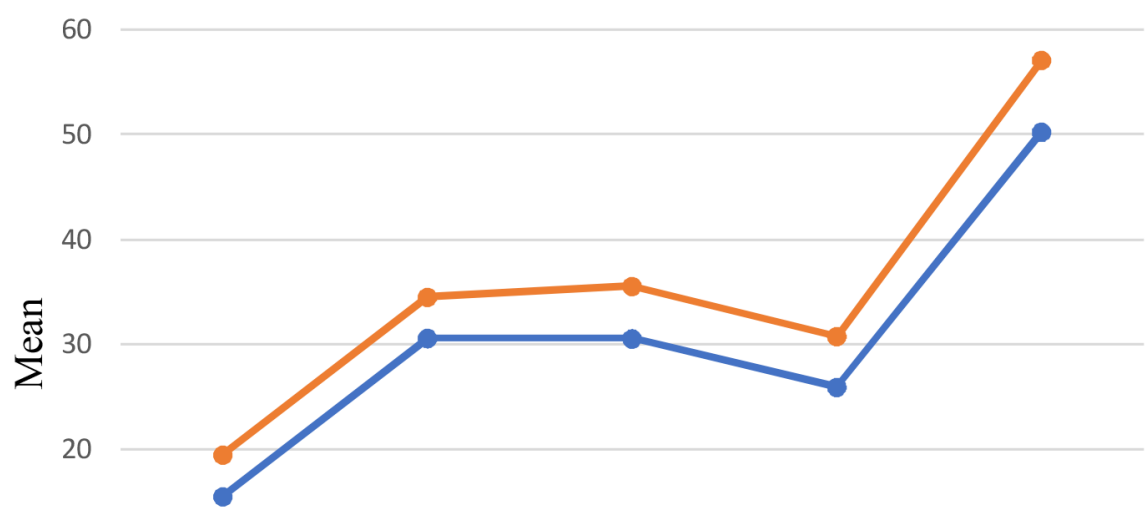

10

0

\begin{tabular}{|c|}
\hline $\begin{array}{l}\text { Intrapersonal } \\
\text { skills }\end{array}$ \\
\hline
\end{tabular}

Emotional Intillegence Factors 
Abdo Hasan AL-QADRI, Wei ZHAO. Emotional intelligence and students' academic achievement

PROBLEMS

OF EDUCATION

IN THE $21^{\text {st }}$ CENTURY

Vol. 79 , No. 3, 2021

372

The fourth research hypothesis: A statistically significant differences in Emotional Intelligence of students according to grade $\left(7^{\text {th }}, 8\right.$ th , and $\left.9^{\text {th }}\right)$ variable. This hypothesis was rejected as follows: grade in emotional intelligence was rejected.

Table 6 displays the mean scores for each of the five dimensions, broken down by grade. No statistically significant variations between the five factors models according to grade variable were observed, highlighting the positive relationship between emotional intelligence and student academic achievement. One way ANOVA has been used for this hypothesis test.

Table 6

The Differences among Students Score of EIS according to the Grade Variable

\begin{tabular}{|c|c|c|c|c|c|c|c|c|c|}
\hline Factor & Grade & $\mathrm{N}$ & M & SD & & $\begin{array}{l}\text { Mean } \\
\text { Square }\end{array}$ & $d f$ & $F$ & $p$ \\
\hline \multirow{3}{*}{$1^{\text {st }}$} & Seventh & 118 & 15.97 & 3.56 & Between Groups & 30.44 & 2 & \multirow{4}{*}{1.93} & \multirow{4}{*}{.15} \\
\hline & Eighth & 93 & 15.63 & 4.32 & Within Groups & 15.81 & 300 & & \\
\hline & Ninth & 92 & 16.75 & 4.12 & \multirow{2}{*}{ Total } & & \multirow{2}{*}{302} & & \\
\hline Total & & 303 & 16.11 & 3.99 & & & & & \\
\hline \multirow{3}{*}{$2^{\text {nd }}$} & Seventh & 118 & 31.56 & 6.55 & Between Groups & 31.40 & 2 & \multirow{4}{*}{.68} & \multirow{4}{*}{.51} \\
\hline & Eighth & 93 & 31.40 & 6.61 & Within Groups & 46.43 & 300 & & \\
\hline & Ninth & 92 & 32.47 & 7.33 & \multirow{2}{*}{ Total } & & \multirow{2}{*}{302} & & \\
\hline Total & & 303 & 31.79 & 6.81 & & & & & \\
\hline \multirow{3}{*}{$3^{\text {rd }}$} & Seventh & 118 & 32.09 & 6.48 & Between Groups & 20.74 & 2 & \multirow{4}{*}{.44} & \multirow{4}{*}{.64} \\
\hline & Eighth & 93 & 31.25 & 7.28 & Within Groups & 46.99 & 300 & & \\
\hline & Ninth & 92 & 31.98 & 6.87 & \multirow{2}{*}{ Total } & & \multirow{2}{*}{302} & & \\
\hline Total & & 303 & 31.80 & 6.84 & & & & & \\
\hline \multirow{3}{*}{$4^{\text {th }}$} & Seventh & 118 & 26.99 & 5.93 & Between Groups & 12.71 & 2 & \multirow{4}{*}{.35} & \multirow{4}{*}{.70} \\
\hline & Eighth & 93 & 26.75 & 5.67 & Within Groups & 35.91 & 300 & & \\
\hline & Ninth & 92 & 27.48 & 6.38 & \multirow{2}{*}{ Total } & & \multirow{2}{*}{302} & & \\
\hline Total & & 303 & 27.07 & 5.98 & & & & & \\
\hline \multirow{3}{*}{$5^{\text {th }}$} & Seventh & 118 & 53.169 & 10.64 & Between Groups & 29.14 & 2 & \multirow{4}{*}{.243} & \multirow{4}{*}{.784} \\
\hline & Eighth & 93 & 52.258 & 10.79 & Within Groups & 119.76 & 300 & & \\
\hline & Ninth & 92 & 52.282 & 11.46 & Total & & 302 & & \\
\hline Total & & 303 & 52.620 & 10.92 & & & & & \\
\hline \multirow{3}{*}{ Overall } & Seventh & 118 & 159.79 & 28.34 & Between Groups & 327.21 & 2 & \multirow{4}{*}{.38} & \multirow{4}{*}{.69} \\
\hline & Eighth & 93 & 157.29 & 29.60 & Within Groups & 872.89 & 300 & & \\
\hline & Ninth & 92 & 160.96 & 30.98 & \multirow{2}{*}{ Total } & & \multirow{2}{*}{302} & & \\
\hline Total & & 303 & 159.38 & 29.48 & & & & & \\
\hline \multirow{3}{*}{$\begin{array}{l}\text { Academic } \\
\text { Achievement }\end{array}$} & Seventh & 118 & 78.31 & 8.79 & Between Groups & 143.79 & 2 & & \\
\hline & Eighth & 93 & 80.39 & 9.69 & Within Groups & 83.22 & 300 & & \\
\hline & Ninth & 92 & 78.23 & 8.94 & \multirow[b]{2}{*}{ Total } & & & & \\
\hline Total & & 303 & 78.92 & 9.14 & & & 302 & 1.73 & .18 \\
\hline
\end{tabular}




\section{Discussion}

PROBLEMS

OF EDUCATION

IN THE $21^{\text {st }}$ CENTURY

Vol. 79, No. 3, 2021

373

The purpose of this study was to determine the possibility of a relationship between Emotional Intelligence (EI) and the academic achievement of Arabic basic school students in China. For reaching this goal, an additional study was to develop a diagnostic tool to be a standard for measuring the Emotional Intelligence of students.

\section{Positive Relationships between the Emotional Intelligence Factors and Academic Achievement of Students for each Model Specifically and Overall}

The acquisition of diverse emotional intelligence may be paramount in the success of a student. Researchers including Cherniss (2001), Goleman (1995), and O'Neil (1996) posited that putting a higher estimate upon emotional intelligence relative to its importance to intellectual quotient (IQ) could be the key to procuring better academic output from students. Several studies have left researchers convinced that there is an unquestionable connection between academic success and emotional intelligence (Ebinagbome et al., 2011). This study aimed to analyze the emotional intelligence of a select number of students. Thus, a comparative analysis of individual students' academic results over an academic year was obtained (Franco et al., 2017; Meshkat $\&$ Nejati, 2017). For statistical analysis, correlation and regression were the methods of choice. The aim of this study was to look into the connection between EI and academic achievement. According to the findings, students' EI was strongly related to their academic achievement. The significant link discovered between EI and student academic achievement could pique curriculum developers' interest in learning more about EI's impact on achievement. Many studies have shown that emotional intelligence has a positive impact on academic performance (Mustafa Ali Khalaf, 2016; Preeti, 2013; Rode et al., 2007). In other studies, the connection between emotional intelligence and achievement was weak but important (Festus, 2012). On the other hand, some studies found no connection between emotional intelligence and academic achievement (Hansenne \& Legrand, 2012; Kashani, Azimi, \& Vaziri, 2012; Pope, Roper, \& Qualter, 2011). The strong link between EI and academic achievement can be explained by the fact that EI encourages people to suppress negative emotions like frustration, self-doubt, tension, and anxiety and instead concentrate on positive emotions like trust, empathy, and congeniality (Sunil \& Rooprai, 2009). For two reasons, Factor 5 (General Mood) was linked to academic achievement. First, academic success necessitates a great deal of self-reliance and strain. Second, the most scholarly study is self-directed, which necessitates a high degree of self-control. As a result, people who are fully conscious of their feelings would do well in school. Zarezadeh (2013) claimed that there is a significant correlation between students' achievement and General Mood. The study of Payton et al. (2000), Parker et al. (2004), and Fatum(2008) founded a positive moderate correlation between emotional intelligence and academic achievement of students (Fatum, 2008). Also, a positive correlation between EI and academic achievement proved by (Yahaya et al., 2012).

In general, the emotional intelligence domains studied in this research are related to academic performance, student achievement, motivation, and matching study of Jennings (2011) since positive emotions are associated with success, while negative emotions are associated with failure. Emotions and priorities, according to Carver \& Scheier (1998), predicted the results as came in the study outcomes of Pekrun, Elliot \& Maier (2009) and were supported by this study (Georgia \& Kourakou., 2018).

The researchers used regression analysis to see if EI is a good predictor of academic success. Regression analysis revealed that all EI variables have a substantial impact on academic achievement. These results are consistent with previous studies conducted by (Mayer \& Salovey, 1997; Nasir \& Masrur, 2010). 
PROBLEMS

OF EDUCATION

IN THE $21^{\text {st }}$ CENTURY Vol. 79 , No. 3, 2021

374

\section{Emotional Intelligence of Students with Five Categories}

From the previous results, students have better abilities at the mood states (the fifth factor). Regarding the general mood state, it is the most important component of emotional intelligence, according to Bar-On, since it is a motivating tool in problem-solving and stress tolerance, in addition to being an integral aspect of interpersonal interaction (Amado-Alonso, León-del-Barco, Mendo-Lázaro, Sánchez-Miguel, \& Iglesias Gallego, 2019). An analysis of the research findings has substantiated the overarching research hypothesis of the investigative team. The findings, as depicted above, show the presence of positive emotional intelligence among students in five domains.

\section{Statistically Significant Differences of Emotional Intelligence of Students according to Gender (males-females) Variable}

Gender (male-female) differences in EIS were analyzed using the independent t-test, and the means indicate statistically significant differences found in EIS. Females are more conscious of their feelings, display more sensitivity, and have better interpersonal skills than males. Alasmari (2014) discovered that females outperformed males in the following EI constructs: stress control, intrapersonal, interpersonal, adaptability, and general mood. They are emotionally intelligent in various ways that males are not due to a specific combination of the key components of EI. Males, on the other hand, are self -confident, optimistic, that the superiority of females in the interpersonal factor confirms the results of previous research (Perdomo et al., 2011; Santesso et al., 2006). Therefore, females show greater competences and abilities than males. These differences between males and females may be due to cultural influences and gender-specific family rearing practices, as other studies have suggested (Conway, 2000; Joseph \& Newman, 2010). Contrary to popular belief, some studies showed that females were not more emotionally intelligent as compared to males (Ahmad, Bangash, \& Khan, 2009). The result contradicted those reported by (Cakan \& Altun, 2005; Depape et al., 2006; Meshkat \& Nejati, 2017) that there was no significant gender differences in terms of EIS. Goleman (1998) reported that there were no gender gaps in EI, stating that while males and females could have different profiles of strengths and weaknesses in different areas of EL, their overall EI levels were equal. However, research conducted by (Mayer, Salovey, \& Caruso, 2000), and more recently (Mandell \& Pherwani, 2003) discovered that in both occupational and personal environments, females were more likely to score higher on measures of EI than males (Stys \& Brown, 2004). Males scored higher in the adaptability and general mood factors, while females scored higher in the interpersonal and intrapersonal factors, as well as Total EQ, according to studies that used the EQ-i as a measuring instrument of EI (Bar-On \& Parker, 2000; Ferrándiz, Hernández, Bermejo, Ferrando, \& Sáinz, 2012; Santesso et al., 2006).

These findings from this study confirmed the outcome of an earlier study by (Fida et al.,2018). Both revealed that there was a notable statistical difference between learners from either gender. Data from the mean scores demonstrated that females outperformed males in all spheres of emotional intelligence. These results have been concretized by similar findings from Fayombo (2012), who discovered an existent link between sex, academic output, and emotional intelligence. The confirmation of a positive and notable association between managing emotions and academic output was made(Fayombo, 2012). An analysis of how learners expressed their feelings, coupled with findings from an independent t-test, showed a skewing of emotional intelligence towards females. Thus, the findings confirmed the long-held view that females are better at expressing their emotions. Studies by Fortin, Oreopoulos, \& Phipps (2015) highlighted the increasing evidential data that male students were becoming less participatory in the education system and were being outperformed by their female counterparts when they become 
participants (MacCann et al., 2020). Here, it can be that this study emphasized several previous studies related to the emotional intelligence field. To clarify these differences, it is necessary to emphasize the importance of going beyond the scope of sexual differences in EI and to encourage non-stereotyped gender identity referents (Conway, 2000). Gender differences in EI have been observed since childhood; this may be due to a difference in emotional instruction between males and females (Brackett \& Salovey, 2006).

\section{Differences of Emotional Intelligence of Students according to Grade $\left(7^{\text {th }}, 8^{\text {th }}\right.$, and $\left.9^{\text {th }}\right)$ Variable}

The findings of this study refute the widely held idea that higher grades lead to increased social and emotional intelligence (Bar-On, 2006) since there was no noticeable correlation between grades and emotional intelligence. The result is consistent with the findings of previous research (Balci-Celik \& Deniz, 2008; Birks, McKendree, \& Watt, 2009; Harrod \& Scheer, 2005).

According to (Genç, Kuluşakl1, \& Aydın, 2016), grade has no effect on any of the subdimensions of the Emotional Intelligence skills scale except problem-solving ability. However, the relationship is quite weak. A meta-analysis study conducted by MacCann in 2020 scoured nine databases, capturing 6139 citations for related emotional intelligence and found a few things. It was revealed a few notable differences in emotional intelligence and resulting in grade disparities between students in both past and present studies (Hermoso et al., 2020). The indication from studies conducted as late as November 1, 2016, stressed the unavailability of study data that showed a significant difference in grade variable based on students' emotional intelligence (C. MacCann et al., 2020). These results reasoned the nature of each study and the research instrument's contents according to its hypotheses and goals.

\section{Conclusions}

This research purposed to calculate the relationship between emotional intelligence and academic achievement of students based on the appropriate validation of emotional intelligence measure. Here, researchers clarified the work, which was done in the whole sections of this research.

First, our conceptualization and the research design included factors identified by BarOn. This dissertation illustrated the analysis of the factors of emotional intelligence through some procedures: started with experts and specialists and pilot test for making sure the face validity and reliability of EIS, then found out construction validity by exploratory and conformity factor analysis for EIS items, which were reported 46 items distributed among 5 factors with appropriate loading for each item and factor as the final formulation of EIS which are, intrapersonal skills, interpersonal skills, stress management, adaptability and general mood. Second, the current research results confirmed the research hypotheses that the relationships among main variables of this research and the factor models for each main variable as emotional intelligence with the academic achievement of students based on the scholastic achievement list which was taken by Arabic schools' principles in China. Furthermore, there was a positive relationship between students' emotional intelligence and their academic achievements, with a statistically significant difference at level 0.01 . Third, the emotional intelligence of students categorized into five levels (very high, high, moderate, low, and very low) for each factor and overall. Fourth, the demographic variables were examined. The study showed that there were statistically significant differences among students according to gender variable, and no statistically significant differences among students according to grade variable.

\author{
PROBLEMS \\ OF EDUCATION \\ IN THE $21^{\text {st }}$ CENTURY \\ Vol. 79, No. 3, 2021 \\ 375
}


PROBLEMS

OF EDUCATION

IN THE $21^{\text {st }}$ CENTURY

Vol. 79 , No. 3, 2021

376

\section{Limitations and Research Directions}

The measures used in this research developed based on theoretical conceptions and several factor models of emotional intelligence (EI) of Bar-On and Parker (2000). EIS had a satisfactory construct validity through several stages started from the researchers reading, revision by specialists and experts in this field, and then applying it for the pilot tests and the emphasis that the scale items to be measured with the five aspects represented five models of emotional intelligence with excluding 14 items for the final EIS formulation as follows (Intrapersonal Skills, Interpersonal Skills, Stress Management, Adaptability, and General mood). So, EIS reliability examined by Cronbach's Alpha, McDonald's Omega, re-test (stability coefficient), CR and AVE. Also, the levels of emotional intelligence were explained. The relationships among the research variables were obtained by Structure Equation Molding (SEM). Data were processed through statistical analysis by EFA and then CFA. Data only sought from 303 students in different grades $\left(7^{\text {th }}, 8\right.$ th , and $\left.9^{\text {th }}\right)$ in Arabic Schools in China and did not demographically represent the context of students from other communities. Therefore, the interpretation of the research results should be cautious in other contexts. The current research illustrated the differences according to gender and grade variables but did not explain the differences according to the school age, country, and years of living in China variables. Thus, it is recommended that future research studies should explore how to expand the constructs in measuring the characteristics of students diagnosed with EIS. So, developing the appropriate programs of emotional intelligence to increase the academic achievement of students are necessary. Besides, it is suggested that future research studies can adopt additional theoretical conceptions for measuring the multiple intelligence, creative thinking, reflective thinking, and critical thinking and their influences on the academic achievement of students in different stages. In addition, this observed relationship between EI and academic achievement should be investigated by considering emotional intelligence measures in future studies. Moreover, ecological validity needs to be further tested by different samples. However, the results of measures development were acceptable, and the hypotheses were accepted except for the grade variable in emotional intelligence, which strengthens the findings of this research.

\section{Acknowledgements}

The authors appreciate the subsidy granted by the Cognitive and Behavior Research Center for Special Needs at Shaanxi Normal University (SNNU) in Xi'an, China, for the study presented here. The authors would like to thank the experts and specialists in this field, as well as the principals and teachers of the four schools that actively participated in this research project, for believing in our project and welcoming us into their daily work, and for allowing us access to their classrooms and students. Additionally, the school of education at SNNU represents the Dean, Vice dean and Professors for continue encouragement.

\section{References}

Ahmad, S., Bangash, H., \& Khan, S. A. (2009). Emotional intelligence and gender differences. Sarhad Journal of Agriculture, 25(1), 127-130.

Al-Qadri, H. A., Wei, Z., Al-khresheh, H. M., Chen, X., \& Hali, U. A. (2018). Teaching competencies for Arabic schools kindergarten teachers in China. The Journal of Social Sciences Research (Special Issue 5), 834-841. https://doi.org/10.32861/jssr.spi5.834.841

Alasmari, A. (2014). Emotional intelligence and academic achievement: A comparative, gender-based study of undergraduate English language learners in Saudi Arabia. Journal of Education and Practice, 5(6), 178-190. 
Amado-Alonso, D., León-del-Barco, B., Mendo-Lázaro, S., Sánchez-Miguel, P., \& Iglesias Gallego, D. (2019). Emotional intelligence and the practice of organized physical-sport activity in children. Sustainability, 11(6), Article 1615. https://doi.org/10.3390/su11061615

Balci-Celik, S., \& Deniz, M. E. (2008). A comparison of Scouts' Emotional Intelligence levels with regards to age and gender variables: A cross-cultural study. Elementary Education Online, 7(2), 376-383. http://ilkogretim-online.org.tr/vol7say2/v7s2m12.pdf

Bar-On. (1997). The Emotional Quotient Inventory (EQ-i): A test of emotional intelligence. Toronto: Multi-Health Systems.

Bar-On. (2003). How important is it to educate people to be emotionally and socially intelligent, and can it be done? Perspectives in Education, 21(4), 3-13.

Bar-On. (2006). The Bar-On Model of Emotional-Social Intelligence (ESI). Psicothema, 18, 13-25

Bar-On, R., \& Parker, J. D. A. (2000). Bar-On Emotional Quotient Inventory: Youth version. Technical manual. Toronto: Multi-Health Systems.

Birks, Y., McKendree, J., \& Watt, I. (2009). Emotional intelligence and perceived stress in healthcare students: A multi-institutional, multi-professional survey. BMC Medical Education, 9, 61. https://doi.org/10.1186/1472-6920-9-61

Boyatzis, R. E., Goleman, D., \& Rhee, K. (2000). Clustering competence in emotional intelligence: Insights from the Emotional Competence Inventory (ECI). In R. Bar-On \& J. D. A. Parker (Eds.), Handbook of emotional intelligence (pp. 343-362). Jossey-Bass, USA. http://www.eiconsortium. org/

Brackett, M., \& Salovey, P. (2006). Measuring emotional intelligence with the Mayer-Salovery-Caruso Emotional Intelligence Test (MSCEIT). Psicothema, 18, 34-41.

Cakan, M., \& Altun, S. A. (2005). Adaptation of an emotional intelligence scale for Turkish educators. International Education Journal, 6(3), 367-372.

Castellan, C. M. (2010). Quantitative and qualitative research: A View for clarity. International Journal of Education, 2(2), 1-14.

Conway, M. (2000). On sex roles and representations of emotional experience: Masculinity, femininity, and emotional awareness. Plenum Publishing Corporation, 43, 687-698.

Coşkun, K., \& Öksüz, Y. (2018). Impact of emotional literacy training on students’ emotional intelligence performance in primary schools. International Journal of Assessment Tools in Education, 36-47. https://doi.org/10.21449/ijate.503393

Deng, L., \& Chan, W. (2017). Testing the difference between reliability coefficients alpha and omega. Educational and Psychological Measurement, 77(2), 185-203. https://doi.org/10.1177\%2F0013164416658325

Depape, A.-M. R., Hakim-Larson, J., Voelker, S., Page, S., \& Jackson, D. L. (2006). Self-talk and emotional intelligence in university students. Canadian Journal of Behavioural Science / Revue canadienne des sciences du comportement, 38(3), 250-260. https://doi.org/10.1037/cjbs2006012

Ebinagbome, M. E., \& Nizam, D. I. (2016). The impact of emotional intelligence on student's academic performance. International Journal of Accounting and Business Management, 4(1), 10-18. http://www.ftms.edu.my/journals/IJABM/Apr2016/10-18.pdf

Fatum, B. A. (2008). The relationship between emotional intelligence and academic achievement in elementary-school children. (Doctoral), The University of San Francisco, San Francisco, California.

Fayombo, G. A. (2012). Emotional intelligence and gender as predictors of academic achievement among some university students in Barbados. International Journal of Higher Education, 1(1). https://doi.org/10.5430/ijhe.v1n1p102

Ferrándiz, C., Hernández, D., Bermejo, R., Ferrando, M., \& Sáinz, M. (2012). Social and emotional intelligence in childhood and adolescence: Spanish validation of a measurement instrument. Journal of Psychodidactics, 17(2), 309-338. http://dx.doi.org/10.1387/Rev.Psicodidact.2814

Festus, A. (2012). The relationship between emotional intelligence and academic achievement of senior secondary students in the federal capital territory. Abuja. Journal of Education \& Practice, 3, 13-19.

Fida, A., Ghaffar, A., Zaman, A., \& Satti, N., A. (2018). Gender comparison of emotional intelligence of university students. Journal of Education and Educational Development, 5(1), 172-188.

Field, A. (2009). Discovering Statistics using SPSS. SAGE.

$\mid \begin{aligned} & \text { PROBLEMS } \\ & \text { OF EDUCATION } \\ & \text { IN THE } 21^{\text {st }} \text { CENTURY } \\ & \text { Vol. 79, No. 3, } 2021\end{aligned}$ 
PROBLEMS

OF EDUCATION IN THE $21^{\text {st }}$ CENTURY Vol. 79 , No. 3, 2021

378

Franco, M. D. G., Beja, M. J., Candeias, A., \& Santos, N. (2017). Emotion understanding, social competence and school achievement in children from primary school in Portugal. Frontiers in Psychology, 8, Article 1376. https://dx.doi.org/10.3389\%2Ffpsyg.2017.01376

Genç, G., Kuluşaklı, E., \& Aydın, S. (2016). The relationship between emotional intelligence and productive language skills. The Reading Matrix, 16(1), 91-105.

Georgia, P., \& Kourakou. (2018). Trait emotional intelligence and achievement goals in EFL. Journal of Contemporary Education, Theory \& Research, 2(1), 27-37. https://www.jcetr.gr/vol2iss1/2-1-5.pdf

Goleman. (1998). Working with emotional intelligence. Bantam.

Hair, J. F., Black, W. C., Babin, B. J., \& Anderson, R. E. (2014). Multivariate data analysis (7th Ed.). Pearson.

Hansenne, M., \& Legrand, J. (2012). Creativity, emotional intelligence, and school performance in children. International Journal of Educational Research, 53, 264268. https://doi.org/10.1016/j.ijer.2012.03.015

Harrod, N. R., \& Scheer, S. D. (2005). An explanation of adolescent emotional intelligence in relation to demographic characteristics. Adolescence, 40(159), 503-512.

Heale, R., \& Twycross, A. (2015). Validity and reliability in quantitative studies. Research Made Simple, 18(3), 66-67. https://doi.10.1136/eb-2015-102129

Henricsson, L., \& Rydell, A.-M. (2006). Children with behaviour problems: The influence of social competence and social relations on problem stability, school achievement and peer acceptance across the first six years of school. Infant and Child Development, 15(4), 347366. https://doi.org/10.1002/icd.448

Hermoso, M., D, T., Frutos, C., R., Rivera, J., F., Salgado, J., G., Iglesias, J., J, G., \& Martín, M., R. (2020). Emotional intelligence and its relationship with emotional well-being and academic performance: The vision of high school students. Children, (7), 2-12. https://doi.org/10.3390/children7120310

Joibari, A., \& Mohammadtaheri, N. (2011). The study of relation between emotional intelligence and students' academic achievement of high schools in Tehran City. Procedia - Social and Behavioral Sciences, 29, 1334-1341. https://doi.org/10.1016/j.sbspro.2011.11.371

Jonker, C., \& Vosloo, C. (2008). The psychometric properties of the Schutte Emotional Intelligence Scale. SA Journal of Industrial Psychology, 34(2), 21-30.

Joseph, D. L., \& Newman, D. A. (2010). Emotional intelligence: An integrative metaanalysis and cascading model. American Psychological Association, 95(1), 54-78. https://doi.org/10.1037/a0017286

Kashani, F. L., Azimi, A. L., \& Vaziri, S. (2012). Relationship between emotional intelligence and educational achievement. Procedia - Social and Behavioral Sciences, 69, 1270-1275. https://doi.org/10.1016/j.sbspro.2012.12.061

Khajehpour, M. (2011). Relationship between emotional intelligence, parental involvement and academic performance of high school students. Procedia - Social and Behavioral Sciences, 15, 1081-1086. https://doi.org/10.1016/j.sbspro.2011.03.242

Ki, E.-J., \& Hon, L. C. (2008). A measure of relationship cultivation strategies. Journal of Public Relations Research, 21(1), 1-24. https://doi.org/10.1080/10627260802520488

MacCann, C., Fogarty, G. J., Zeidner, M., \& Roberts, R. D. (2011). Coping mediates the relationship between emotional intelligence (EI) and academic achievement. Contemporary Educational Psychology, 36(1), 60-70. https://psycnet.apa.org/doi/10.1016/j.cedpsych.2010.11.002

MacCann, C., Jiang, Y., Brown, L. E. R., Double, K. S., Bucich, M., \& Minbashian, A. (2020). Emotional intelligence predicts academic performance: A meta-analysis. Psychological Bulletin, 146(2), 150-186. https://doi.org/10.1037/bul0000219

Mandell, B., \& Pherwani, S. (2003). Relationship between emotional intelligence and transformational leadership style: A gender comparison. Journal of Business and Psychology, 17(3), 387-404.

Mayer, \& Salovey, P. (1997). What is emotional intelligence: In P. Salovey, \& D. Sluyter (Eds.), Emotional development and emotional intelligence: Implications for educators. Basic Books.

Mayer, Salovey, P., \& Caruso, D. (2000). Models of emotional intelligence. In Handbook of Intelligence (pp. 396-420). https://doi.org/10.1017/CBO9780511807947.019

Meshkat, M., \& Nejati, R. (2017). Does emotional intelligence depend on gender? A study on undergraduate English majors of three Iranian universities. SAGE Open, 7(3). https://doi.org/10.1177\%2F2158244017725796 
Mortan, R. A., Ripoll, P., Carvalho, C., \& Bernal, M. C. (2014). Effects of emotional intelligence on entrepreneurial intention and self-efficacy. Revista de Psicología del Trabajo y de las Organizaciones, 30(3), 97-104. https://doi.org/10.1016/j.rpto.2014.11.004

Mustafa Ali Khalaf, A. (2016). The relationship between emotional intelligence and academic achievements in males and females in Egyptian context. Journal of Psychology Research, 6(10). http://www.davidpublisher.org/index.php/Home/Article/index?id=28452.html

Nasir, M., \& Masrur, R. (2010). An exploration of emotional intelligence of the students of IIUI in relation to gender, age, and academic achievement. Bulletin of Education \& Research, 32, 37-51.

Parker, J., Summerfeldt, L., Hogan, M., \& Majeski, S. (2004). Emotional intelligence and academic success: Examining the transition from high school to university. Personality and Individual Differences, 36, 163-172.

Perdomo, D. M. C., Pérez-Olmos, I., \& Pinilla, M. I. (2011). Inteligencia emocional en adolescentes de dos colegios de Bogotá* [Emotional Intelligence (EI) in Adolescents from Two Schools in Bogotá]. Revista Colombiana de Psiquiatría, 40(1), 49-64. https://doi.org/10.1016/s0034-7450(14)601049

Pope, D., Roper, C., \& Qualter, P. (2011). The influence of emotional intelligence on academic progress and achievement in UK university students. Assessment \& Evaluation in Higher Education, 37(8), 907-918. https://doi.org/10.1080/02602938.2011.583981

Preeti, B. (2013). Role of emotional intelligence for academic achievement for students. Research Journal of Educational Sciences, 1(2), 8-12.

Rode, J. C., Mooney, C. H., Arthaud-Day, M. L., Near, J. P., Baldwin, T. T., Rubin, R. S., \& Bommer, W. H. (2007). Emotional intelligence and individual performance: Evidence of direct and moderated effects. Journal of Organizational Behavior, 28(4), 399-421. https://doi.org/10.1002/job.429

Santesso, D., Reker, D. L., Schmidt, L. A., \& Segalowitz, S. J. (2006). Frontal electroencephalogram activation asymmetry, emotional intelligence, and externalizing behaviors in 10-year-old children. Child Psychiatry and Human Development, 36(3), 311-328. https://doi.org/10.1007/s10578-0050005-2

Scherer, R. (2015). Is it time for a new measurement approach? A closer look at the assessment of cognitive adaptability in complex problem solving. Frontiers in Psychology, 6, 1664. https://doi.org/10.3389/fpsyg.2015.01664

Shearer, C. (2004). Using a Multiple intelligences assessment to promote teacher development and student achievement. Teachers College Record, 106(1), 147-162. http://dx.doi.org/10.1111/j.1467-9620.2004.00325.x

Sternberg, R. J. (2015). Successful intelligence: A model for testing intelligence beyond IQ tests. European Journal of Education and Psychology, 8(2), 76-84. https://doi.org/10.1016/j.ejeps.2015.09.004

Stys, Y., \& Brown, S. (2004). A review of the emotional intelligence literature and implications for corrections. Correctional Service of Canada. https://www.csc-scc.gc.ca/research/r150-eng.shtml

Sunil, K., \& Rooprai, K. (2009). The role of emotional intelligence in managing stress and anxiety at workplace. Paper presented at the ASBBS Annual Conference, Las Vegas.

Taherdoost, H. (2016). Sampling methods in research methodology; how to choose a sampling technique for research. International Journal of Academic Research in Management (IJARM), 5(2), 18-27.

Vahedi, M., \& Nikdel, H. (2011). Emotional intelligence, parental involvement and academic achievement. Procedia - Social and Behavioral Sciences, 30, 331-335. https://doi.org/10.1016/j.sbspro.2011.10.065

Van Rooy, D. L., \& Viswesvaran, C. (2004). Emotional intelligence: A meta-analytic investigation of predictive validity and nomological net. Journal of Vocational Behavior, 65(1), 71-95. https://doi.org/10.1016/s0001-8791(03)00076-9

Watkins, M. W. (2017). The reliability of multidimensional neuropsychological measures: From alpha to omega. The Clinical Neuropsychologist, 31(6-7), 11131126. https://doi.org/10.1080/13854046.2017.1317364

Woitaszewski, S. A., \& Aalsma, M. C. (2004). The contribution of emotional intelligence to the social and academic success of gifted adolescents as measured by the multifactor emotional intelligence scale - adolescent version. Roeper Review, 27(1), 25-30. https://doi.org/10.1080/02783190409554285

Yahaya, A., Juriah, N., Bachok, D., Yahaya, N., Boon, Y., Hashim, S., \& Le, G. (2012). The impact of emotional intelligence element on academic achievement. Archives Des Sciences, 65(4), 2-17.

$\mid \begin{aligned} & \text { PROBLEMS } \\ & \text { OF EDUCATION } \\ & \text { IN THE } 21^{\text {st }} \text { CENTURY } \\ & \text { Vol. 79, No. 3, } 2021\end{aligned}$

379 
Abdo Hasan AL-QADRI, Wei ZHAO. Emotional intelligence and students' academic achievement

PROBLEMS

OF EDUCATION

IN THE $21^{\text {st }}$ CENTURY

Vol. 79, No. 3, 2021

380

Yazici, H., Seyis, S., \& Altun, F. (2011). Emotional intelligence and self-efficacy beliefs as predictors of academic achievement among high school students. Procedia - Social and Behavioral Sciences, 15, 2319-2323. https://doi.org/10.1016/j.sbspro.2011.04.100

Zahed-Babelan, A., \& Moenikia, M. (2010). The role of emotional intelligence in predicting students' academic achievement in distance education system. Procedia - Social and Behavioral Sciences, 2(2), 1158-1163. https://doi.org/10.1016/j.sbspro.2010.03.164

Zarezadeh, T. (2013). The effect of emotional intelligence in English language learning. Procedia - Social and Behavioral Sciences, 84, 1286-1289. https://doi.org/10.1016/j.sbspro.2013.06.745

Zulkipli, I., \& Ali, H. (2018). Strategic leadership: Realizing student aspiration outcomes. Partridage publishing.

Received: March 18, 2021

Accepted: June 04, 2021

Cite as: Al-Qadri, A. B., \& Zhao, W. (2021). Emotional intelligence and students academic achievement. Problems of Education in the $21^{\text {st }}$ Century, 79(3), 360-380. https://doi.org/10.33225/pec/21.79.360

Abdo Hasan Al-Qadri

$\mathrm{PhD}$, School of Education, Shaanxi Normal University,

Xi'an, China.

E-mail: lubna23112015@outlook.com

ORCID: https://orcid.org/0000-0002-9276-6534

Wei Zhao

(Corresponding author)
PhD, Department of Special Education, School of Education, Shaanxi Normal University, 199 South Chang'an Road, Xi'an, 710062 Shaanxi, China.

Email: zhaowei@snnu.edu.cn

ORCID: https://orcid.org/0000-0003-4660-5155 